\title{
India in "Flattening the Curve" of COVID-19 Pandemic - Triumphs and Challenges Thereof
}

\author{
Devamsh Arora ${ }^{1}$, Muskan Sharmaㄹ, Sourya Acharya ${ }^{3}$, Samarth Shukla ${ }^{4}$, Neema Acharya ${ }^{5}$ \\ 1, 2, 3 Department of Medicine, Datta Meghe Institute of Medical Sciences (Deemed to Be University), Sawangi \\ Meghe, Wardha, Maharashtra, India. ${ }^{4}$ Department of Pathology, Datta Meghe Institute of Medical Sciences \\ (Deemed to Be University), Sawangi Meghe, Wardha, Maharashtra, India. ${ }^{5}$ Department of OBG, Datta Meghe \\ Institute of Medical Sciences (Deemed to Be University), Sawangi Meghe, Wardha, Maharashtra, India.
}

ABSTRACT

\section{BACKGROUND}

We often see the term flattening the curve in newspaper and news but we often forget the very importance of this term which if considered seriously can be used to deal with various pandemic situations around the globe and one such condition is Covid19 which is being dealt by each one of us in this World. The "Curve" which all the researchers in the world are commenting upon is the one which states the number of people that will come in contact with Covid-19 over a particular period of time. This curve will tell you about the theoretical spread of the virus and will help different governments around the world to predict the outcome of such a condition and plan various measures which can be used to deal with this situation we all are living with. The use of pandemic curve can be traced back in time and how it has benefitted mankind since time immemorial. The origin of the strategy of flattening the curve can be traced back in a newspaper named Interim pre pandemic planning guidance: community strategy for pandemic influenza mitigation in US: early, targeted, layered use of non-pharmaceutical interventions. The center for disease control and preventions published it in 2007, a paper which gave a preview about this impactful strategy and about how this could be used in a pandemic like situation. To win this battle against the novel coronavirus, infection Covid-19; epidemiologists are using this strategy of "Flattening the Curve"; but in this strategy in addition to social distancing there is a significant requirement to increase the surge capacity of hospitals. Different data is coming from different region's which tells that diverse actions are being taken in different countries. This review will have a look at the Indian scenario of flattening the curve along with all the strategies applied and their success rate.

\section{KEY WORDS}

Curve, COVID-19, Epidemiologist, Corona Virus

\author{
Corresponding Author: \\ Dr. Sourya Acharya. \\ Department of Medicine, Datta Meghe \\ Institute of Medical Sciences (Deemed to Be \\ University), Sawangi Meghe, Wardha, \\ Maharashtra. \\ E-mail: souryaacharya74@gmail.com
}

DOI: $10.14260 / \mathrm{jemds} / 2020 / 713$

How to Cite This Article:

Arora D, Sharma M, Acharya S, et al. India in "flattening the curve" of COVID-19 pandemic - triumphs and challenges thereof. J Evolution Med Dent Sci 2020;9(43):3252-3255, DOI: $10.14260 /$ jemds/2020/713

Submission 01-06-2020,

Peer Review 15-09-2020,

Acceptance 21-09-2020,

Published 26-10-2020.

Copyright (c) 2020 Devamsh Arora et al. This is an open access article distributed under Creative Commons Attribution License [Attribution 4.0 International (CC BY 4.0)] 


\section{BACKGROUND}

\section{What is Curve? And What is the Need to Flatten It?}

Curve studies or more commonly known as epidemic curve which is also known as epidemiological curve or epi curve is a graphical representation to visualize the onset of a disease outbreak, it tells us about the increase in the rate of cases compared the time of disease outbreak. Along with the increase in the cases one can also find out about the incubation period, its trend with time and contagiousness of the disease.1,2 From 30 January 2020, when the first Corona case was found out in Kerala India, till the mid of May that is within 3 months the confirmed cases have crossed a mark of over 1 lacs and the death toll over 4000 already [30th Jan $2020-25^{\text {th }}$ May 2020]. This is the reason that we need to flatten the curve in the shortest span possible.

Epidemiologist along with other researchers who study how the diseases spread like the one novel coronavirus by plotting a graph known as "epidemic curve". The epidemic curve is a two-dimensional curve with the number of cases marked in x-axis and the time span in y-axis. Similarly, the Covid-19 pandemic is also plotted in epidemic of to keep an account of the number of cases rising every day. The graph can take any shape, but the most common pattern seen are steep curve and the flatten curve.

In steep curve the case grows exponentially meaning the total number of infections continue to double at a consistent rate which means one week it is 5000 case second week 10000 case $3^{\text {rd }}$ week 20,000 case and it continue so on. This pattern was shown by many developed countries including China, Italy America, which was mainly due to not taking proper measures at the correct time like social distancing, working from home, avoiding social gatherings, shutting down: college's, schools, offices, temples and churches. In steep curve pattern the cases skyrockets to its peak within few months with infecting most of the individual creating a havoc. The faster, cases rise more is the burden created at the healthcare system which code in little span of time beyond the capacity to treat people as seen in Italy. The country experienced this heart wrenching situation by itself, this scenario would take lot of life along with hospital running out of basic supplies and would in fact would leave everyone with nothing behind. And after infecting almost everyone to its capacity it would fall at the same rate.

In India, the situation was handled in a very different manner as Corona reached quite late here, due to which Government got some time to handle the situation of havoc calmly. First case of Covid-19 in India was reported on $30^{\text {th }}$ of January in Kerala region, when a student of India originally from Wuhan (origin of first case of Corona worldwide) came back from his homeland to continue his studies. When the cases started to increase in India, government took its first very step to stop the steepening of this curve. They started screening airports by infrared thermometer and followed the WHO norms of quarantine whom so ever was screened positive for fever and sore throat. Even after this measure cases started to rise in India as there were more of asymptomatic carriers leading to increase in case to around 470 mark on $21^{\text {st }}$ March 2020. In a measure of this government announced a Janata Curfew of 14 hours (7 A.M. to 9 P.M.) to be followed on 22nd March 2020 as a respectful gesture towards frontline fighters such as medical and paramedical staff, police, delivery service, in short all those who were still engaged in providing the essential services to the people of the nation. Exactly at 8 p.m. people who were not involved directly in frontline services were to take part in curfew by clapping or ringing bells in order to appraise them. Following Janata Curfew, a very bold step was carried out by the government by declaring nationwide lockdown (1.0) starting from 24th March 2020 till 14th April 2020. Varies rules were laid down and anyone who would have failed to follow the rules would have been behind the bars for a period of 1 year. As per the rules, lockdown restricts people from stepping out of their home and all the transportation services such as railway, flights, buses, taxis were suspended except for essential good transportation. All educational institutes across the county were shut down completely. Essential services such as food shops, banks and ATM, petrol pump were exempted from the lockdown rules but they were to follow rules of social distancing and mask was made compulsory.

\section{Lockdown 2.0}

Due to nationwide lockdown 1.0 observers noted a decline in the doubling rate of cases due to which government further decided to extend the lockdown till $3^{\text {rd }}$ May 2020 with some relaxation starting from $20^{\text {th }}$ April 2020 such as allowing business relating to agriculture as well as shops which were selling supplies related to farming. Public sectors were even allowed to reopen with instructions to follow social distancing. Transportation sector was even given relief including cargo trucks, planes and trains with social distancing norms.

On $16^{\text {th }}$ April 2020 India was divided into 3 category zones which were as follow:

Green Zone - with no Covid cases in the past 21 days.

Orange Zone - potential infectious hotspot.

Red Zone - definite infectious hotspot.

\section{Lockdown 3.0}

Government of India after observing the situation of increasing no of cases to flatten the curve decided to extend lockdown period further for more 2 weeks ( $4^{\text {th }}$ May $2020-17^{\text {th }}$ May 2020) and gave guidelines which was to be followed according to zone you were confined to. These guidelines were as follows:

1. Inter / intra district buses with $50 \%$ capacity were allowed in Green zone only.

2. Taxis with 1 driver and passengers were allowed only in green and orange zone.

3. Private offices with $33 \%$ capacity were allowed in all the zones and so on.

\section{Lockdown 4.0}

On 17th May government decided to extend the lockdown further till $31^{\text {st }}$ of May and basically obliterated the idea of zones that is same rules would be applicable all over the country. There were many reliefs which were given amid this lockdown. Most of the things starting from public transportation to markets, all the things were opened across the country (except in containment zone). All manufacturing units including factories, supply line and offices were allowed to function without any restrictions. Buses and private vehicles are even allowed to be used. ${ }^{3}$ 


\section{Things Which Continue to Be on a Ban}

Even after the relaxations given there are some guidelines which has to be followed as per the government. These include restriction on air travel-domestic as well as international and metro transportation due to large crowd gathering. But there will be limited availability of train travel for the migrants and common public who are struck at their work places due to sudden announcement of lockdown. Education institutes will continue to remain closed along with restaurants, movie theatres, malls, gyms and swimming pools. People can still avail the service of home delivery instead of dining out which is an alternative. All gathering associated with a huge crowd such as marriage, social, political and religious function will continue to be barred and places of worship will remain shut.

\section{WHERE DID INDIA GO WRONG? THE CHALLENGES FACED}

All over the world due to various lockdown restriction we must say that earth got a better place to live in. Sky is much cleaner; water bodies are bluer, and animals are living with less of cruelty this time. Mother Nature has started to heal all because of this lockdown. But does that mean that humans are all safe? The answer to this is no. Even after these strict measures there were some flaws which were missed by our beloved country. The scenario might have been a bit less of a havoc if these mistakes were avoided at that time itself. Some of these biggest mistakes which took place were:

\section{Late Suspension of Air Travel}

In January India was well aware about the fact that corona virus has started to travel nations even amid the lockdowns which were being followed by some of the countries. At that time a strict action would have implicated a better result in the control of current pandemic situation in India. Instead of banning on International or domestic travel, India chose the path of screening. But some airports across the nation, didn't took the decision of screening much seriously. On 17th January, India stared to issue some travel advisories to China.

On $5^{\text {th }}$ February, it finally made a total restriction for foreign nationals who were to travel in India from China, although many countries had already stated about the alarming increase of corona cases around the world. India even after knowing such golden information continued travel of foreign nationals of Iran, Japan, Italy and South Korea. It was not before $22^{\text {nd }}$ March 2020 after much thinking and chaos and with a total of 2,90,000 cases approximately across the globe that India finally took a firm decision of curbing air transportation. These 2 months that is between $17^{\text {th }}$ January $2020-22^{\text {nd }}$ March 2020 there were more than 15 lakh foreign nationals who traveled to India and none of them were screened for anything other than high body temperature. As per the recent research of WHO there are more than 30 percent asymptomatic carriers than presymptomatic transmissions.

This careless approach of government towards international travel at that time which was practically the only source of transmission of infection has actually been a much of disaster to this country. Even the decision of domestic lockdown of at least 3 weeks without a prior notice has led many people stranded thousands of miles from their home and the lockdown triggered a mass mob to travel by foot, leading a huge toll on the lives and livelihoods. This all could have been prevented if the management of airport reacted well to the screening of travelers or if the flights were restricted much before this havoc. ${ }^{4}$

\section{Shortage of Basic Protective Gear}

India has $2^{\text {nd }}$ largest population in the world. Even after 1.3 billion people living in this country, our government has only invested a GDP of $1.6 \%$ on the health care sector, which is one among the lowest in the world. After facing the current pandemic situation, the government along with the citizens have realized that without a good health sector, a country is just a hollow building without concrete pillars. Due to low PPE Kits all over the country, the frontline workers who were the only hope started to fall apart. How would a healthcare worker protect citizens of its country without protecting himself / herself? Being aware of the fact that India has 1 doctor over 1000 people, the shortage of PPE made this fact even worse than a nightmare. Doctors all over the country started to boycott their clinics, they started protest over PPE and some even filed formal complaints about the shortage of PPE kits. This story was further true with the mechanical ventilators. There was already a shortage of ventilators in almost all the hospitals and it was the only equipment which was well prepared to tackle the respiratory symptoms of the corona virus suffered patient. India might need 1 million ventilators in near future if the current situation does not ease soon enough.

\section{Shortage of Testing Kits and Delaying Domestic Production}

India even after being one of the most populated country in the world is short of testing kits for Covid-19. As per reports, the state-run labs were operating at a capacity of just $36 \%$. Even after facing this pandemic late compared to other countries, Indian government failed to realize the fact about how short of testing kit we were. At this time, country at least needs 10,000 tests per million of population, it is just working at a rate of 1500 test per million of population even after implicating 4 lockdowns in the country. India even managed to place an order of around 1 million testing kits from Germany but as a latecomer the kits never arrived. Due to this ICMR had ordered tests from Indian distributors for two Chinese firms Zhuhai Livzon Diagnostics Incand Guangzhou Wondfo Biotech. But these kits were not up to the mark which further led to a dispute between ICMR and Wondfo Biotech which revealed ICMR were ready to pay Rs. 600 for test that costs only Rs. 245 leaving a margin of around $145 \%{ }^{4}$

\section{Low Testing Rate}

As per data analysis shown by ICMR, India around $10^{\text {th }}$ April 2020 was testing for Covid-19 at a rate of 10.5 test per million people which was even considered to be too low for district level. At that time some countries such as South Korea and Iceland were busy testing at a rate much higher than India (600 to 2600 times respectively). By analysing the growth curve of Covid-19 in India ICMR on $11^{\text {th }}$ April 2020 decided to 
expand the testing rate to fight this pandemic. If this step would have been taken earlier then better prophylaxis measures could have been thought to fight this pandemic situation.

\section{4 $4^{\text {th }}$ May 2020 'Black Day of Lockdown'}

India took one of the boldest steps in the history by shutting down a population of 1.33 billion people completely for at least a month. Even after being well aware of the fact that India was at $3^{\text {rd }}$ stage of Covid-19 spread and this would thrash down its very own citizens, government didn't hesitate to go against its very own citizen. But even after taking such bold steps (like lockdown), a big mistake was on its way. On 1st May 2020 Indian government decided to open liquor shops all around the country (except in containment zone) from $4^{\text {th }}$ May 2020 under the pressure of fallen economy and compulsion of various stages. Due to thirst of liquor long queues were seen crowding up across the nation as long as $4 \mathrm{Kms}$ which were a tragic moment as it took down all the efforts of lockdown in vein. After this decision it was noticed that doubling rate across the country increased which lead to some strict measures to follow across all the liquor shop which included social distancing and not more than 5 people were allowed to stay in queue.

\section{Denial of Community Spread}

Earlier, India was at a constant state of denial of community transmission of Covid-19. Even ICMR turned down and stated that they have not witnessed any community transmission in India. The actual reality was that India at the start of this pandemic was not even in the condition to test out 100 people per day leading to masking of the very fact of community transmission. Not before $20^{\text {th }}$ March 2020, none of the health sector came forward to be transparent enough about the community transmission of this contagious disease. Even health ministry denied this fact and was not transparent with its own citizens. At the time India accepted the fact of community transmission I guess by then Corona was already surfing across varies cities in India.

\section{CONCLUSIONS}

Mother Nature is healing. Skies are much transparent than before; oceans are much bluer than before. I guess the very sin of this world itself has led to this healing. If this situation would have never arrived, then we all would have been living in this false world of false beliefs about how cheap the value of a life is. If this pandemic would have never happened, then the GDP would have been $1.6 \%$ (or less!) in the health sector which is actually the very root of this country. India even though took some bold steps in dealing with this pandemic situation failed to lower the curve to the extent it should have. If only our country had realised the importance of closing the borders, investing in health sector, valuing its own healers, then I guess the scenario would have been drastically different than what it is today. If the world realized the value of life over money, then I guess we all would have been living in a better and controllable curve right now. As it has been said since time immemorial that "prevention is better than cure", we actually got busy in finding the cure than following the very own meaning of this phrase. But it still is not too late. Let's fight this situation together and follow the very basics of social distancing and using a mask when we go out in this world and prevent the spread of this disease.

Financial or other competing interests: None.

Disclosure forms provided by the authors are available with the full text of this article at jemds.com.

\section{REFERENCES}

[1] https://www.fastcompany.com/90476143/the-storybehind-flatten-the-curve-the-defining-chart-of-the coronavirus

[2] https://en.wikipedia.org/wiki/Epidemic_curve

[3] https://en.wikipedia.org/wiki/COVID19_pandemic_lockdown_in_India

[4] https://thewire.in/health/five-covid-19-policymistakes-india-could-have-done-without 